\title{
Rethinking the History of American Freedom
}

\section{Citation}

Michael J. Klarman, Rethinking the History of American Freedom, 42 Wm. \& Mary L. Rev. 265 (2000).

\section{Published Version}

http://scholarship.law.wm.edu/wmlr/vol42/iss1/6/

\section{Permanent link}

http://nrs.harvard.edu/urn-3:HUL.InstRepos:12965060

\section{Terms of Use}

This article was downloaded from Harvard University's DASH repository, and is made available under the terms and conditions applicable to Other Posted Material, as set forth at http:// nrs.harvard.edu/urn-3:HUL.InstRepos:dash.current.terms-of-use\#LAA

\section{Share Your Story}

The Harvard community has made this article openly available.

Please share how this access benefits you. Submit a story.

Accessibility 


\section{William \& Mary Law Review}

Volume 42 | Issue 1

Article 6

\section{Rethinking the History of American Freedom}

Michael J. Klarman

\section{Repository Citation}

Michael J. Klarman, Rethinking the History of American Freedom, 42 Wm. \& Mary L. Rev. 265 (2000), http://scholarship.law.wm.edu/wmlr/vol42/iss1/6

Copyright c 2000 by the authors. This article is brought to you by the William \& Mary Law School Scholarship Repository. 


\title{
REVIEW ESSAY
}

\begin{abstract}
RETHINKING THE HISTORY OF AMERICAN FREEDOM (REVIEW ESSAY OF ERIC FONER, THE STORY OF AMERICAN FREEDOM (1998))
\end{abstract}

\section{MICHAEL J. KLARMAN*}

Professor Eric Foner is one of the most distinguished American historians of our time. His definitive work on Reconstruction ${ }^{1}$ garnered numerous awards and has become a widely used source among American constitutional historians and constitutional lawyers. Now Foner has written another book that should be of at least equal interest to the legal academy. The Story of American Freedom is a massively researched and extraordinarily learned work, which fully reflects the three decades' worth of reading and thought that Professor Foner has invested in his subject. The book is also, as with Foner's other work, beautifully written. Every lawyer and law professor in America would do well to read this book.

American Freedom covers virtually every topic touching on the subject of American freedom from the American Revolution to the

* James Monroe Professor of Law and F. Palmer Weber Research Professor of Civil Liberties and Human Rights, University of Virginia School of Law. This review essay grew out of remarks delivered at a panel session on Professor Foner's book, The Story of American Freedom (1998), which took place at the University of Virginia School of Law on March 2, 2000. I benefitted from the remarks delivered by Professor Foner on that occasion and am grateful to him for supporting the idea of converting my panel remarks into a review essay. I would like to thank the students on the William \& Mary Law Review for inviting me to publish this essay in their journal. It was my pleasure to teach several of them during the fall semester of 1999, when I was the Distinguished Lee Visiting Professor at the MarshallWythe School of Law at the College of William and Mary.

1. ERIC FONER, RECONSTRUCTION: AMERICA'S UNFINISHED REVOLUTION, 1863-1877 (1988). 
Reagan Revolution. Freedom is canvassed in all of its multifarious guises-political, economic, social, consumerist, etc. Foner is particularly adept at capturing the ironies that characterize the story of American freedom. The book begins with an American nation, conceived in liberty and dedicated to the proposition that all men are created equal, yet heavily dependent on slave labor (p. 3). The story ends with the Reagan Revolution and its reconceptualization of freedom-a universe in which the term "Freedom Fighters" is used to describe anti-Sandanista guerillas seeking to overthrow a democratically elected government in Nicaragua, but never an African National Congress trying to overthrow a vicious white supremacist regime in South Africa, and in which an economic bill of rights refers not to providing jobs or subsistence to the poor, but rather to dismantling economic regulation of corporations, cutting taxes, and reducing the power of labor unions (p. 321). What appears in between these bookend ironies is too rich and multifaceted to lend itself to easy summary. I will not even attempt such a task here. Suffice it to say that anyone interested in the history of American freedom-which ought to be everyoneshould read this book.

Indeed American Freedom is so wide ranging and the concept of freedom is shown to encompass so many diverse meanings that one begins to wonder if "freedom" really has any bite to it. In Part I of this review essay, I suggest that Foner's plenitude of examples illustrating the contestability and malleability of freedom actually suggest that the concept is vacuous. In Parts II and III, I offer a few of my own interpretations of the book's data. First, I shall suggest some possible explanations for why particular freedoms expand over time. That is, I shall consider the circumstances and conditions under which particular freedoms prosper. Then I shall turn to a question that receives surprisingly little attention from Professor Foner-what is the role of courts in the story of American freedom?

\section{The MALLEABILITy OF THE CONCEPT OF FREEDOM}

A dominant theme of American Freedom is the contested nature of freedom throughout American history. Professor Foner is so successful at demonstrating the malleability of freedom in his- 
torical debates that skeptics may question whether the concept has any bite to it at all. First, let us consider a few examples of the wide variety of historical debates in which freedom has been invoked on both sides. Then, we can identify the characteristics of freedom that render it such a malleable concept. Finally, we can evaluate whether freedom is so manipulable as to be vacuous, and, if so, consider the implications.

One pervasive theme of American Freedom is the invocation of freedom on both sides of various economic disputes throughout American history. Mid-nineteenth-century Whigs viewed freedom as a product of energetic government creating the conditions for economic growth, while Jacksonian Democrats, likewise in the name of freedom, opposed government intervention in the economy as conferring special privileges upon the advantaged few (pp. 5354). Half a century later, during the Gilded Age, this same debate reappeared in the guise of Lochner Era courts invalidating economic reform legislation as inconsistent with liberty of contract, while Populists and Progressives argued contemporaneously that genuine freedom was impossible without government regulation of unaccountable corporations, support for labor unions, and some mild redistribution of wealth (pp. 115-30). This same debate continued to rage another half century later, as President Franklin D. Roosevelt defined the nation's objectives during the Second World War in terms of the Four Freedoms-not only freedom of speech and religion, but also freedom from want and fear. Contrast the perspective of Roosevelt's opponents in the Liberty League and the Republican Party who disparaged freedom from want and fear as New Deal freedoms, rather than American freedoms, and urged inclusion of a fifth freedom on the list-freedom of private enterprise (pp. 227-30).

Foner's point about the contestability of the concept of freedom in American history is not limited to economic examples. He contrasts, for example, a conventional, perhaps male-oriented conception of freedom that sanctifies a private sphere of family autonomy secure from government regulation, with a feminist notion of freedom that demands government intervention against the unfreedom that characterizes a private sphere in which men use their disproportionate economic and physical power to subordinate 
women (pp. 80-83). Or consider the abortion debate, where one side emphasizes the freedom of women to control their reproduction, and the other underscores the freedom of unborn children to live ( $p$. 319). Or compare the Civil Rights Movement's conception of freedom as the right of African Americans to enjoy equal access to jobs, housing, and public accommodations regardless of race, with Barry Goldwater's statements in the 1964 presidential campaign that fair employment legislation violated the freedom of employers, with Ronald Reagan's declarations during the 1966 California guber-natorial campaign that fair housing legislation violated the freedom of homeowners (pp. 314-15). Finally, and perhaps most strikingly, consider the northern and southern perspectives on freedom evinced during the Civil War. Northerners, at least after Lincoln's Emancipation Proclamation, fought for the freedom of slaves. Southerners equally fought for freedom-the freedom to regulate their own "domestic institutions" independent of federal control and the freedom not to be deprived of their property in slaves (p. 95). ${ }^{2}$ I say this last point is most striking because if even the slavery issue was debated by both sides in terms of freedom, one is entitled to wonder whether any substantive position on any important public policy debate cannot be so defended.

The various examples cited above indicate two reasons why the concept of freedom is so malleable. First, as Professor Foner rightly observes, the struggle between positive and negative conceptions of freedom has persisted throughout American history (e.g., pp. xviii, 53-54, 129-30). Negative liberty is the freedom from government interference. Positive liberty is the existence of conditions enabling individuals to realize their potential or accomplish their goalsconditions that may be attainable only through government intervention in a private sphere which, if left unregulated, inhibits the realization of genuine freedom. Foner shows, perhaps surprisingly, that Americans have always embraced both these competing conceptions of freedom. So long as positive and negative

2. "We all declare for liberty; but in using the same word, we do not all mean the same thing. With some the word liberty may mean for each man to do as he pleases with himself, and the product of his labor; while with others the same word may mean for some men to do as they please with other men, and the product of other men's labor." Lincoln's Address at Sanitary Fair, Baltimore, Maryland (Apr. 18, 1864), in ABRAHAM LINCOLN: SPEECHES AND WRITINGS, 1859-1865, at 589 (Don E. Fehrenbacher ed., 1989). 
conceptions of freedom are equally valid, freedom arguments are certain to exist on both sides of every significant public policy dispute. $^{3}$ Women want to be free of government interference with their reproductive choices; abortion opponents want the government to guarantee the fetuses' freedom to live. The National Rifle Association wants to be free of government interference with the right to keep and bear arms, while residents of high-crime urban neighborhoods want the government to regulate guns so that they may enjoy freedom to walk the streets uninhibited by constant fear of gun-related violence. The equal validity of positive and negative conceptions of liberty makes it impossible to choose between the two sides of these debates solely in terms of the quality of their freedom arguments.

Second, freedom conceived as an individual right operates as a "trump" against legislative majorities. ${ }^{4}$ Yet freedom conceived as a political right entails the capacity of democratic majorities to control their destinies through legislation. ${ }^{5}$ Again, so long as both these conceptions of freedom are equally valid, freedom arguments necessarily will exist on both sides of every policy debate. The individual freedom of women to reproductive choice is in tension with the political freedom of democratic majorities to regulate abortion, a subject upon which the Constitution arguably does not speak. ${ }^{6}$ The individual freedom of gays and lesbians to avoid government discrimination based on sexual orientation is inconsistent with the political freedom of democratic majorities to define the moral bounds of their community. ${ }^{7}$ Without privileging or disqualifying one of these competing conceptions of freedom, equally respectable freedom arguments are certain to appear on both sides of every policy dispute.

If these two observations about freedom are correct, then I wonder if Professor Foner can be right when he states that, although freedom "is a contested concept, it is not merely an empty

3. This is one of the fundamental points made in LOUIS MICHAEL SEIDMAN \& MARKV. TUSHNET, REMNANTS OF BELIEF: CONTEMPORARY CONSTITUTIONAL ISSUES (1996).

4. See, e.g., RONALD DWORKIN, TAKING RIGHTS SERIOUSLY (1977).

5. See, e.g., JoHN HART ELY, DEMOCRACY AND DISTRUST (1980).

6. Compare Roe v. Wade, 410 U.S. 113 (1973), with Doe v. Bolton, 410 U.S. 179, 221-22 (1973) (White, J., dissenting).

7. Compare Romer v. Evans, 517 U.S. 620 (1996), with id. at 636, 653 (Scalia, J., dissenting). 
vessel" (p. xvii). If the positive/negative and individual/political conceptions of freedom are equally valid, and thus freedom can be invoked with equal plausibility on either side of any significant political debate, then why isn't freedom a vacuous concept, an "empty vessel"? Perhaps I am mistaken, but I suspect that by demonstrating the infinite contestability and malleability of freedom, Foner has proven that the concept does no serious work in the various debates in which it is invoked.

This is not to say, of course, that all arguments about freedom are equally convincing. It is to say that the reason some such arguments are more persuasive than others has nothing to do with their merit as arguments about freedom, but rather is attributable to the attractiveness of the substantive cause on behalf of which they are mustered. The southern slaveowners who invoked the freedom to take their slave property into federal territories as a basis for invalidating the Missouri Compromise in Dred Scott $v$. Sandfor $d^{8}$ were not making a conceptually flawed freedom argument. Protection of property rights against government interference and insistence upon the limited scope of federal regulatory power are time honored freedom arguments. The slaveowners' claim fails to resonate with us in the year 2000 not because it misapplies the concept of freedom, but rather because we no longer regard property in human beings as the sort of freedom that warrants protection. Similarly, white Southerners who criticized Brown v. Board of Education ${ }^{9}$ as an invasion of their freedom did not misunderstand the concept. The freedom of local communities to govern their own schools and of individuals to choose with whom they associate have long and respected historical pedigrees. Such freedom arguments are unpersuasive to us today not because they misconstrue the concept of freedom, but rather because we no longer choose to respect the freedom of those who denigrate other human beings because of their race or to defer to the freedom of local political majorities to use their power in the service of white supremacy.

Foner's compelling, if unintended, demonstration of freedom's infinite malleability thus yields an important lesson. Freedom,

\footnotetext{
8. 60 U.S. (19 How.) 393 (1857).

9. 347 U.S. 483 (1954).
} 
much like equality, ${ }^{10}$ is an empty concept. To say that one favors freedom is really to say nothing at all. As is so often the case in constitutional law, one ultimately cannot avoid taking a position on the merits. Whether freedom is good or bad depends entirely on the particular substantive cause on behalf of which freedom is invoked.

\section{WHEN DOES FREEDOM PROSPER?}

Although Professor Foner does not explicitly address this point, the material canvassed in American Freedom bears directly on a question of great importance to students of American freedom: Under what conditions do particular liberties prosper and expand? ${ }^{11}$ Let me suggest three explanations for why the stock of certain freedoms rises over time. These accounts are neither mutually exclusive nor exhaustive. I offer them simply as my own speculation as to why particular freedoms have prospered at certain moments in American history.

First, a particular liberty may become more attractive because it is intimately associated with a substantive cause that has gained popularity. For example, as Foner notes, during the first third of the twentieth century, freedom of speech was closely identified with the labor movement (p. 164). Specifically, freedom of speech was generally understood to mean the right of labor unions to organize, picket, and boycott. ${ }^{12}$ As a result of the Great Depression and the New Deal, the political and social status of organized labor grew tremendously during the 1930s. It is no accident that by the end of that decade, the Supreme Court for the first time had extended First Amendment protection to labor union picketing, pamphleting,

10. See Peter Westen, The Empty Idea of Equality, 95 HARV. L. REv. 537 (1982).

11. Just to be clear, I emphasize that there is no tension between this point and the one made in the preceding part. The lesson of Part I was that as one freedom expands, another freedom necessarily contracts. For example, an expansion of the freedom of gunowners contracts the freedom of likely victims of gun-related violence. My focus in this Part is on the conditions that facilitate the expansion of particular freedoms. The expansion of those particular freedoms necessarily means a contraction of some other set of freedoms.

12. This paragraph draws on the more expanded discussion in Michael J. Klarman, Rethinking the Civil Rights and Civil Liberties Revolutions, 82 VA. L. REv. 1, $39-42$ (1996). See also Geoffrey D. Berman, Note, A New Deal for Free Speech: Free Speech and the Labor Movement in the 1930s, 80 VA. L. REV. 291 (1994). 
and organizing. ${ }^{13}$ Similarly in the 1950 s and 1960 s, free speech became intertwined with another substantive cause that was beginning to prosper-the Civil Rights Movement. ${ }^{14}$ Again, it is no accident that many of the landmark free speech decisions of the Warren Court emanated from civil rights controversies. ${ }^{15}$

The Warren Court's criminal procedure revolution may be another example of how particular freedoms expand when associated with substantive causes that are gaining in popularity. Most criminal defendants are poor, and a disproportionate number are members of minority racial groups. The 1960s witnessed both a Civil Rights Movement and a War on Poverty. There is little doubt that the Warren Court Justices thought about criminal procedure issues in terms of race and wealth discrimination. ${ }^{16}$ The Court's first forays into regulating state criminal procedure in the 1920s and 1930s mainly came in cases of egregious mistreatment of black defendants by the criminal justice system of southern states. ${ }^{17}$ Yet as late as the 1960s, at least some Justices continued to think about criminal procedure cases in racial terms. ${ }^{18}$ Likewise, the connection between criminal procedure rights and poverty could not be missed in cases such as Gideon $v$. Wainwright, ${ }^{19}$ and lay only slightly beneath the surface in cases like Miranda $v$. Arizona. ${ }^{20}$

A second explanation for the advance of particular freedoms focuses on war. This connection is ironic, because in the short term, wartime exigencies seem to diminish freedom. Examples of this (1939).

13. See, e.g., Thornhill v. Alabama, 310 U.S. 88 (1940); Hague v. C.I.O., 307 U.S. 496

14. See HARRY KALVEN, JR., THE NEGRO AND THE FIRST AMENDMENT (1965).

15. See, e.g., New York Times v. Sullivan, 376 U.S. 254 (1964); NAACP v. Button, 371 U.S. 415 (1963); NAACP v. Alabama, 357 U.S. 449 (1958).

16. I have elaborated on this argument in Klarman, supra note 12, at 62-65.

17. See Brown v. Mississippi, 297 U.S. 278 (1936); Norris v. Alabama, 294 U.S. 587 (1935); Powell v. Alabama, 287 U.S. 45 (1932); Moore v. Dempsey, 261 U.S. 86 (1923). I have investigated the connection between race and the origins of modern criminal procedure at greater length in Michael J. Klarman, The Racial Origins of Modern Criminal Procedure, 99 MICH. L. REV. (forthcoming Oct. 2000).

18. See BERNARD SchWARTZ, SUPERCHIEF: EARL WARREN AND HIS SUPREME COURT-A JUdICIAL BIOGRAPHY 591 (1983); Louis Michael Seidman, Brown and Miranda, 80 CAL. L. REV. 673, 678, 750-51 (1992).

19. 372 U.S. 335 (1963).

20. 384 U.S. 436 (1966); see William J. Stuntz, Waiving Rights in Criminal Procedure, 75 VA. L. REV. 761, 837-38 (1989). 
phenomenon abound. Military detention and trial of civilians was widespread during the Civil War. ${ }^{21}$ The Sedition and Espionage Acts of 1917-18 were used to suppress criticism of the Wilson administration's conduct during World War I. ${ }^{22}$ World War II resulted in a massive interference with the freedom of Japanese Americans. ${ }^{23}$ The Cold War provided the occasion for substantial impingements upon freedom of speech and due process. ${ }^{24}$

Yet American wars also have produced longer term advances in freedom, especially by expanding the pool of freedom's beneficiaries. ${ }^{25}$ The Revolutionary War led to the First Emancipation of slaves in the North and a temporary increase in individual manumissions in parts of the South. ${ }^{26}$ The Civil War not only emancipated the slaves, but also expanded the civil and political rights of the Freedmen. ${ }^{27}$ It is no accident that women received the right to vote through federal constitutional amendment during World War I. ${ }^{28}$ World War II was the proximate cause of the modern Civil Rights Movement. ${ }^{29}$ It also proved a fruitful source of free speech growth. Jehovah's Witnesses, for example, won the right to abstain from saluting the flag during World War II-a right that had been denied to them through the late 1930s. ${ }^{30}$

War may expand particular freedoms for a variety of reasons. First, Americans tend to define their war aims in democratic terms.

21. See, e.g., MARK E. NEELY, JR., THE FATE OF LIBERTY: ABRAHAM LINCOLN AND CIVIL LIBERTIES (1991).

22. See, e.g., PAUL L. MURPHY, WORLD WAR I AND ThE ORIGIN OF CIVLLIBERTIES IN THE UNTED STATES (1979).

23. See, e.g., PETER Irons, JUSTICE AT WAR (1983).

24. See, e.g., RICHARD M. FRIED, NIGHTMARE IN RED:THE MCCARTHY ERA IN PERSPECTIVE (1990).

25. For a similar claim, see PHIIIP A. KLINNKER \& Rogers M. SMITH, ThE UNSTEAdY MARCH: THE RISE AND DECLINE OF RACIAL EQUALITY IN AMERICA (1999).

26. See, e.g., ARTHURZILVERSMIT, THEFIRST EMANCIPATION: THEABOLITION OF SLAVERY IN THE NORTH 109-12, 117-19, 227-29 (1967).

27. See, e.g., FONER, supra note 1, at 114-15, 223, 244-45, 255; JAMEs M. McPHERSON, ABRAHAM LINCOLN AND THE SECOND AMERICAN REVOLUTION 29-37 (1990).

28. See Eleanor FlexNer, CENTURY OF STRUgGle: THE WOMAN'S Rights MOVEMENT IN THE UNITED STATES 294 (1975).

29. See, e.g., JoHn DitTMER, LoCAl PeOple: The STRugGle For Crvil RighTs IN MississipPI ch. 1 (1994); ADAM FAIRClough, RACE \& DEMOCRACY: THE CIVIL RIGHTS STRUGGLE IN LOUISIANA, 1915-1972, at ch. 4 (1995).

30. See West Virginia State Bd. of Educ. v. Barnette, 319 U.S. 624 (1943); DAVID R. MANWARING, RENDER UNTO CAESAR: THE FLAG-SALUTE CONTROVERSY 72 (1962). 
World War I was the war "to make the world safe for democracy." World War II was fought against fascism and the multitude of unfreedoms it represented. How much the articulation of war aims in ideological terms affects the fate of American freedom is a complex question that cannot be resolved here. It must be conceded that most white Southerners showed remarkable creativity in rationalizing a war against fascism while preserving their own commitment to white supremacy. ${ }^{31}$ But other Americans, less heavily invested in the maintenance of Jim Crow, could not escape the cognitive dissonance inherent in fighting against $N$ azi doctrines of Aryan supremacy with a segregated army. ${ }^{32}$ The Supreme Court, unable to reconcile the war's democratic ideology with the continued disfranchisement of southern blacks, finally invalidated the white primary in $1944 .^{33}$ The Court likewise invalidated sterilization of recidivist criminals with a disapproving, thinly veiled reference to the eugenic experiments of Nazi scientists. ${ }^{34}$ Another Court ruling in 1940 expanded the due process ban on coerced confessions with a disparaging allusion to the law enforcement tactics of totalitarian nations. ${ }^{35}$ Finally, the Justices who invalidated the compulsory flag salute in 1943 cannot have been oblivious to the fact that it was Hitler who first put Jehovah's Witnesses on the world map by persecuting them for refusing to heil the Fuhrer. ${ }^{36}$ Apparently, at least in the chambers of Supreme Court Justices, ideologically articulated war aims force some reconciliation of national principles with national practices.

Wars also may advance the cause of certain freedoms through their general dislocative effects. Wars, especially total ones like the Civil War and World War II, undermine traditional patterns of status and behavior. President Lincoln decided to emancipate and

31. See, e.g., Johnpeter Horst Grill \& Robert L. Jenkins, The Nazis and the American South in the 1930s: A Mirror Image?, 58 J. S. HIST. 667 (1992).

32. See, e.g., NEIL R. MCMILLEN, DARK JOURNEY: BLACK MISSISSIPPIANS IN THE AGE OF JiM CRow 317 (1989); Michael J. Klarman, Brown, Racial Change and the Civil Rights Movement, 80 VA. L. REv. 7, 23-26 (1994) (citing sources).

33. See Smith v. Allwright, 321 U.S. 649 (1944).

34. See Skinner v. Oklahoma, 316 U.S. 535,541 (1942).

35. See Chambers v. Florida, 309 U.S. 227, 241 (1940).

36. See West Virginia State Bd. of Educ. v. Barnette, 319 U.S. 624 (1943); MANWARING, supra note 30 , at $30-31,123,154$. 
then to arm the slaves only after a year-long effort to suppress disunionism without disrupting traditional racial patterns had proved unavailing. ${ }^{37}$ The women's suffrage movement, which for nearly three-quarters of a century had failed to secure a constitutional amendment enfranchising women, finally triumphed during World War I, when military conscription and industrial preparedness reduced the male labor supply sufficiently to force popular acceptance of women assuming nontraditional economic and social roles. ${ }^{38}$ The extraordinary manpower demands created by World War II likewise opened unprecedented civil and military opportunities for African Americans and thus accelerated the breakdown of traditional patterns of racial subordination. ${ }^{39}$ Blacks moved from South to North and from farm to city, creating new opportunities for the exercise of political power and the organization of social protest. African Americans returning from military service were far less inclined to passively endure the oppressive racial status quo. The disruption of world relations caused by the war resulted in a new international order, in which Americans had to choose between altering their racial practices and sacrificing their pretensions to leadership of a largely nonwhite Third World that had some justification for identifying American capitalist democracy with racial oppression. ${ }^{40}$

Finally, war usually involves common sacrifice for the general good and thus has inescapably egalitarian implications. The sacrifices of the Freedmen on Civil War battlefields helped secure postwar constitutional amendments guaranteeing basic civil and political rights to African Americans. ${ }^{41}$ The contributions of women on the home front during the First World War helped push the women's suffrage movement over the top. ${ }^{42}$ The battlefield sacrifices

37. See, e.g., David Herbert Donald, LinColn ch. 13 (1995); JAMES M. MCPhERSON, BATTLE CRY OF FREEDOM: THE CIVIL WAR ERA ch. 16 (1988).

38. See FleXNER, supra note 28, at 298-99.

39. For the rest of this paragraph, see sources cited in Klarman, supra note 32, at 14-23.

40. See, e.g., Mary L. Dudziak, Desegregation as a Cold War Imperative, 41 STAN. L. REV. 61 (1988).

41. See, e.g., William GilletTe, The Right to Vote: Politics and the Passage of the FIFTEENTH AMENDMENT 81, 85 (1965); EARL M. MALTZ, CIVIL RIGHTS, THE CoNSTITUTION, AND CONGRESS, 1863-1869, at 6 (1990).

42. See FLEXNER, supra note 28 , at 298-99. 
of American Catholics during that same war paved the way for their accelerated assimilation into the nation's cultural mainstream during the 1920s and 1930s, as America's unofficial Protestant establishment began slowly to crumble. ${ }^{43}$ If African Americans were good enough to fight and die for their country during World War II, surely they were good enough to vote and to deserve federal government protection against lynching and other racially motivated violence. ${ }^{44}$

Whatever the precise causal mechanism, American wars often have advanced the cause of particular freedoms, especially by expanding the pool of beneficiaries.

A perusal of American history suggests a third way in which particular freedoms expand-through a backlash effect generated by opponents overplaying their hand. Examples are plentiful; I shall limit myself to a few, particularly salient instances. The Sedition Act of 1798, deployed aggressively by Federalists to suppress Republican criticism of the Adams administration, apparently produced a backlash against seditious libel prosecutions and in favor of a broader conception of free speech. ${ }^{45}$ Widespread mob violence against abolitionist speakers and newspaper editors in northern states during the 1830 s-including tarring and feathering, destruction of printing presses, and one particularly salient murder-ultimately generated a backlash in favor of the free speech rights of these antislavery agitators. ${ }^{46}$ A couple thousand criminal prosecutions under the Espionage and Sedition Acts during World War I-targeting not only anarchists and communists, but also socialists, pacifists, and civil libertarian critics of the Wilson administration-inspired the creation of the American Civil Liberties Union and probably facilitated the Supreme Court's inauguration of modern First Amendment doctrine a decade later. ${ }^{47}$

43. See, e.g., ROBERT T. HANDY, UNDERMINED ESTABLISHMENT: CHURCH-STATE RELATIONS IN AMERICA, 1880-1920, at 189-90 (1991).

44. See, e.g., ROBERT J. NORRELl, REAPING THE WHIRLWIND: THE CIVIL RIGHTS MOVEMENT IN TUSKEGEE 57 (1985); NEIL A. WYNN, THE AFRO-AMERICAN AND THE SECOND WORLD WAR 29 (1976).

45. See, e.g., LEONARD W. LEVY, EMERGENCE OF A FREE PRESS chs. 9-10 (1985).

46. See Michael Kent Curtis, The Curious History of Attempts to Suppress Antislavery Speech, Press, and Petition in 1835-37, 89 Nw. U. L. REV. 785 (1995).

47. See, e.g., MURPHY, supra note 22; SAMUEL WALKER, IN DEFENSE of AMERICAN 
Hitler and his Nazi Holocaust resulted in a dramatic expansion in the freedom of American Jews after World War II. ${ }^{48}$ Perhaps the most famous exemplar of this backlash phenomenon is the mobilization of national opinion behind the enactment of landmark civil rights legislation in 1964 and 1965 in direct response to the televised scenes of police brutalization of civil rights demonstrators in Birmingham and Selma, Alabama. ${ }^{49}$ It is possible that we are witnessing a similar phenomenon today, as the notorious homophobic murders of Matthew Shepard in Wyoming and of Private Barry Winchell at Fort Campbell, Kentucky may be generating a backlash in favor of gay rights. ${ }^{50}$

This backlash dynamic is ironic, but probably not surprising. It is common wisdom that a profitable strategy in politics is to induce one's opponents to overplay their hand. The same is true in the story of American freedom.

\section{THE ROLE OF COURTS IN THE STORY OF AMERICAN FREEDOM}

From a law professor's perspective, the most striking feature of American Freedom may be the minimal role that courts play in the story. I noticed just one reference to a court decision in the book's first hundred pages, and that was to Dred Scott, where the freedom protected by the Court was that of Southerners to take their slaves into the federal territories (p. 75). Courts continue to play a de minimus role throughout the remainder of American Freedom. For example, Brown v. Board of Education, probably the most famous case in the history of the United States Supreme Court, is the subject of just two index references; each is to a single sentence that mentions the decision almost in passing (pp. 258-59, 314). Many lawyers surely would criticize Foner for unduly minimizing the role

LIBERTIES: A HISTORY OF THE ACLU chs. 1-2 (1990).

48. See, e.g., EDWARD S. SHAPIRO, A TMME FOR HEALING: AMERICAN JEWRY SINCE WORLD WAR II chs. 1-2 (1992).

49. See, e.g., GLenN T. Eskew, BUT fOR Birmingham: The Local and National MOVEMENTS IN THE CIVL Rights STRUGGLe chs. 8-9 (1997); DAVID J. GARROW, ProteST at SELMA: MARTIN LUTHER KING, JR., AND THE VOTING RIGHTS ACT OF 1965 (1978); Klarman, supra note 32, at 141-49 (citing additional sources).

50. See, e.g., Kenneth Sherrill \& Alan Yang, From Outlaws to In-laws, Anti-Gay Attitudes Thaw, 11 PUB. PERSP. 20 (Jan. 2000). 
of courts in the story of American freedom. Yet I found his eschewal of court fetishism refreshing. Leave it to a history professor to remind us lawyers that, in the grand scheme of things, courts have played a relatively marginal role in the history of American freedom. That is not to say no role at all, but rather a fairly small one.

I have three points to make about the role of courts in the story of American freedom. First, and most importantly, courts are less important to this story than most lawyers, and probably many historians (though not Foner), believe. ${ }^{51}$ One reason is that American history reveals that "courts love liberty most when it is under pressure least."52 This insight should come as no surprise: Judges are part of contemporary culture and thus are exceedingly unlikely to interpret the Constitution in ways that depart dramatically from contemporary public opinion. ${ }^{53}$ Examples of the Court failing to intervene on behalf of freedom when most needed are legion. The Supreme Court never lifted a finger against the most massive deprivation of freedom in American history, African American slavery, and on several occasions intervened on its behalf. ${ }^{54}$ Likewise, the Court legitimized segregation and disfranchisement for much of the Jim Crow era, ${ }^{55}$ upheld seditious libel prosecutions during World War $\mathrm{I},{ }^{56}$ validated the Japanese American internment during World War II, ${ }^{57}$ sanctioned persecution of alleged Communists during the McCarthy era, ${ }^{58}$ and

51. For some typical statements, see the sources cited in Klarman, supra note 12, at 1-3 nn.1-14.

52. John P. Frank, Review and Basic Liberties, in SUPREME COURT AND SUPREME LAW 109, 114 (Edmond Cahn ed., 1954).

53. See generally Klarman, supra note 12.

54. See, e.g., Ableman v. Booth, 62 U.S. (21 How.) 506 (1859); Dred Scott v. Sandford, 60 U.S. (19 How.) 393 (1857); Prigg v. Pennsylvania, 41 U.S. (16 Pet.) 536 (1842). See generally William M. Wiecek, Slavery and Abolition Before the United States Supreme Court, 1820 1860,65 J. AM. HIST. 34 (1978).

55. See, e.g., Giles v. Harris, 189 U.S. 475 (1903); Williams v. Mississippi, 170 U.S. 213 (1898); Plessy v. Ferguson, 163 U.S. 537 (1896). See generally Michael J. Klarman, The Plessy Era, 1998 SUP. CT. REV. 303.

56. See, e.g., Debs v. United States, 249 U.S. 211 (1919); Schenck v. United States, 249 U.S. 47 (1919).

57. See Korematsu v. United States, 323 U.S. 214 (1944).

58. See, e.g., Dennis v. United States, 341 U.S. 494 (1951); American Communications Ass'n v. Douds, 339 U.S. 382 (1950). 
approved sex discrimination until after the emergence of the modern women's movement. ${ }^{59}$

Even when the Court has invoked the Constitution on behalf of freedom causes that are widely celebrated today, as often as not it has deployed an emerging or existing national consensus to suppress outlier state practices. Many of the Court's most famous freedom decisions exemplify this paradigm: Griswold $v$. Connecticut ${ }^{60}$ (striking down a state ban on contraceptive use, as applied to married couples); Gideon $v$. Wainwright ${ }^{61}$ (requiring state-appointed defense counsel in all felony cases); Pierce $v$. Society of Sisters ${ }^{62}$ (invalidating a state law barring children from attending private school); Harper $v$. Virginia Board of Elections ${ }^{63}$ (striking down the poll tax); Nixon $v$. Herndon ${ }^{64}$ (barring a state-mandated white primary); and Moore v. City of East Cleveland ${ }^{65}$ (invalidating legislation denying certain blood relatives the right to live in a single household). In all of these cases, the Court's ruling had the effect of invalidating laws in no more than a small handful of states; additional examples easily might be cited. Invoking the Constitution to invalidate extreme outlier practices hardly represents a momentous contribution to the story of American freedom.

Even in the civil rights context, where the conventional wisdom regarding the instrumental role of courts in the story of American freedom is especially entrenched, ${ }^{66}$ the judicial contribution is easily

59. See, e.g., Hoyt v. Florida, 368 U.S. 57 (1961); Goesaertv. Cleary, 335 U.S. 464 (1948); Ruth Bader Ginsburg, Sexual Equality Under the Fourteenth and Equal Rights Amendments, 1979 WASH. U. L.Q. 161, 162-64.

60. 381 U.S. 479 (1965); see Mary L. Dudziak, Just Say No: Birth Control in the Connecticut Supreme Court Before Griswold v. Connecticut, 75 Iowa L. REv. 915, 920 (1990).

61. 372 U.S. 335 (1963); see John F. Decker \& Thomas J. Lorigan, Comment, Right to Counsel: The Impact of Gideon v. Wainwright in the Fifty States, 3 CREIGHTON L. REV. 103, 104 (1970).

62. 268 U.S. 510 (1925); see WILLIAM G. ROSS, FORGING NEW FREEDOMS: NATTVISM, EDUCATION, AND THE CONSTITUTION, 1917-1927, at 134, 148 (1994).

63. 383 U.S. 663 (1966); see id. at 666 n.4.

64. 273 U.S. 536 (1927); see DARLENE CLARK HINE, BLACK VICTORY: THE RISE AND FALL OF THE WHITE PRIMARY IN TEXAS 47-49 (1979).

65. 431 U.S. 494 (1977); see Robert A. Burt, The Constitution of the Family, 1979 SUP. CT. REV. 329, 391.

66. See, e.g., JACK GREENBERG, CRUSADERS IN THE CoURTS: How a DediCated BaND OF LAWYERS FOUGHT FOR THE CIVIL RIGHTS REVOLUTION (1994); RICHARD KLUGER, SMPLe 
exaggerated. Most of the Supreme Court's interventions on behalf of African Americans prior to World War II were limited in scope and utterly trivial in consequence. ${ }^{67}$ Brown $v$. Board of Education, the most celebrated of all Court decisions, was rendered possible only by the dramatic changes in racial attitudes and practices set in motion by the New Deal and World War II. ${ }^{68}$ A decade or two earlier, when a decision invalidating public school segregation would have been dramatically countermajoritarian (and almost certainly unenforceable), ${ }^{69}$ the Justices did not seriously think of rendering it. ${ }^{70}$ Nor, once decided, did Brown produce significant results until the national political branches had mobilized behind it. ${ }^{71}$ That development was a product of the Civil Rights Movement, not Brown, and the one had less to do with the other than is traditionally assumed. ${ }^{72}$ None of this is to deny, however, that the NAACP's litigation campaign played a significant role in mobilizing African Americans to protest the racial status quo, or that early Court victories may have provided an inspirational ray of hope in an otherwise barren landscape. ${ }^{73}$ It is to say that Court decisions, including Brown, played relatively little role in undermining Jim Crow practices and that the critical battles of the Civil Rights Movement were fought on the streets of southern cities, not in courtrooms.

JUSTICE: THE HISTORY OF BROWN V. BOARD OF EDUCATION AND BLACK AMERICA'S STRUGGLE FOR EQUALITY (1976).

67. Both the cases and their consequences are discussed in Klarman, supra note 55; Michael J. Klarman, Race and the Court in the Progressive Era, 51 VAND. L. REV. 881 (1998); Klarman, supra note 17.

68. See Klarman, supra note 32, at 7-75.

69. See MichaEl. J. KLARMAN, NEITHER HERo, NOR VILLAIN: THE SUPREME COURT, RACE ANDTHECONSTTTUTIONINTHE TWENTIETH CENTURY ch. 3 (forthcoming) (manuscript at 48-51, 62-63, on file with William and Mary Law Review).

70. See Gong Lum v. Rice, 275 U.S. 78 (1927); Memorandum of William O. Douglas (Jan. 25, 1960), in The DOUGLAS LeTters: SELECTIONS FROM THE PRIVATE PAPERS OF JUSTice WILLIAM O. DOUGLAS 169 (Melvin I. Urofsky ed., 1987) (noting a Frankfurter statement in 1960 to the effect that he would have voted to uphold segregation in the 1940s had such a case reached the Court, because "public opinion had not then crystallized against it").

71. See, e.g., Gerald N. Rosenberg, The Hollow Hope: CaN Courts Bring ABout SOCIAL CHANGE? chs. 2-3 (1991).

72. I have developed this argument at some length in Klarman, supra note 32, at 75-150.

73. See, e.g., Klarman, supra note 67, at 946-52; Klarman, supra note 17 (manuscript at 43-45, on file with William and Mary Law Review). 
Recent advances in the freedom of women and gays and lesbians even more obviously have been secured without any significant contribution from the Court. The women's liberation movement already had become a vibrant force in national politics before the Justices invalidated their first sex classification in $1971 .^{74}$ Though the Court did strike down many more such laws over the ensuing decade ${ }^{75}$ most of these interventions were relatively trivial in their implications-chopping down some dead legislative wood is not much of an overstatement. ${ }^{76}$ Moreover, the Court declined to intervene against legislation embracing some of the most harmful sex stereotypes, ${ }^{77}$ and, in one remarkable decision, denied that pregnancy classifications were sex related.$^{78}$ Similarly, dramatic advances in the freedom of gays and lesbians secured over the past few decades have been won almost entirely without judicial assistance. ${ }^{79}$

Again, none of this is to deny that occasionally the Supreme Court does strike blows in defense of freedoms that do not enjoy majoritarian support. Clearly, the Court's decisions invalidating school prayer or flag-burning prohibitions and protecting the procedural rights of criminal suspects have not commanded majority support. ${ }^{80}$ Yet even with regard to these decisions, it is important to appreciate the limits of the Court's inclination and capacity to frustrate majority opinion. The Justices invalidated school prayer and Bible reading only after the relative demise of the nation's unofficial Protestant establishment, ${ }^{81}$ and these decisions

74. See Reed v. Reed, 404 U.S. 71 (1971).

75. See, e.g., Mississippi Univ. for Women v. Hogan, 458 U.S. 718 (1982); Craig v. Boren, 429 U.S. 190 (1976); Frontiero v. Richardson, 411 U.S. 677 (1973).

76. See, e.g., JOHN C. JEFFRIES, JR., JUSTICE LEWIS F. POWELL, JR. 511 (1994).

77. See, e.g., Rostker v. Goldberg, 453 U.S. 57 (1981); Michael M. v. Superior Court, 450 U.S. 464 (1981).

78. See Geduldig v. Aiello, 417 U.S. 484 (1974).

79. Romer v. Evans, 517 U.S. 620 (1996), is the only Supreme Court decision guaranteeing the equal protection rights of gays and lesbians, and it invalidated an obvious outlier statute.

80. See, e.g., Texas v. Johnson, 491 U.S. 397 (1989); Miranda v. Arizona, 384 U.S. 436 (1966); Engel v. Vitale, 370 U.S. 421 (1962). For the polls on flag burning and school prayer, see Barry Friedman, Dialogue and Judicial Review, 91 MICH. L. REv. 577, 606 n.142, 608 n.155 (1993).

81. See Klarman, supra note 12 , at $46-62$. 
were widely defied in practice. ${ }^{82}$ Likewise, the Warren Court's criminal procedure revolution was rendered possible only by shifting public attitudes toward race, poverty, and totalitarian law enforcement practices; ${ }^{83}$ subsequent Courts have significantly retrenched upon it, ${ }^{84}$ and the practical effect of decisions expanding the freedom of criminal suspects has been largely blunted by the unwillingness of legislatures to adequately fund defense counsel. ${ }^{85}$

Second, to the limited extent that judicial decisions have influenced the story of American freedom, they have been as likely to hinder as to advance the cause of particular liberties. This point is directly related to one made earlier: Because the concept of freedom plausibly can be invoked on either side of virtually any historical controversy, when the Court advances one brand of freedom, it necessarily infringes upon another. For example, when the Court defends under the First Amendment the freedom of affluent people to spend money on influencing elections, ${ }^{86}$ it undermines the freedom of other people to enjoy an electoral process uncorrupted by the influence of money. A court that defends the right of gun owners to keep and bear arms simultaneously abridges the freedom of persons living in high-crime urban areas to enjoy lives unimpaired by the constant fear of gun-related violence. When the Supreme Court defends the freedom of women to control their reproduction through abortion, ${ }^{87}$ it nullifies the freedom of fetuses to live. Once one concedes that freedom has a positive as well as a negative component, as discussed above, an advance for one freedom cause necessarily represents a setback for another.

Even setting this point aside and focusing on one particular brand of freedom, calculating whether courts have advanced or

82. See, e.g., FrankJ. SORAUF, The Wallof SeParation: The Constitutional Politics oF ChURCH AND STATE 296-300 (1976); H. Frank Way, Jr., Survey Research on Judicial Decisions: The Prayer and Bible Reading Cases, 21 W. POL. Q. 189 (1968).

83. See Klarman, supra note 12 , at $62-66$.

84. See, e.g., United States v. Leon, 468 U.S. 897 (1984) (establishing the good faith exception to the exclusionary rule); New York v. Quarles, 467 U.S. 649 (1984) (recognizing the exigent circumstances exception to Miranda warnings).

85. See William J. Stuntz, The Uneasy Relationship Between Criminal Procedure and Criminal Justice, 107 YALE L.J. 1 (1997).

86. See, e.g., Buckley v. Valeo, 424 U.S. 1 (1976).

87. See Roe v. Wade, 410 U.S. 113 (1973). 
retarded its cause over the course of American history is extremely complicated. For example, has the Supreme Court been more of a help or a hindrance to the cause of African American liberation over the past two centuries? The answer seems genuinely uncertain to me. On the one hand, the Supreme Court struck many early blows against the "legal lynchings" of black criminal defendants, gradually chipped away at southern state mechanisms for disfranchising blacks, ${ }^{89}$ and invalidated (eventually) racial segregation in housing and public education. ${ }^{90}$ On the other hand, the same Court also invalidated northern personal liberty laws designed to protect free blacks from kidnapping by slavecatchers, ${ }^{91}$ voided Congress's effort to restrict the spread of slavery into federal territories while simultaneously denying that even free blacks possessed any rights "which the white man was bound to respect," struck down the 1875 Civil Rights Act provision guaranteeing blacks "full and equal" access to public accommodations, ${ }^{93}$ legitimized racial segregation and black disfranchisement for many decades early in the twentieth century, ${ }^{94}$ and in the last decade or so has invalidated numerous affirmative action plans and minority voting districts ostensibly designed to benefit African Americans. ${ }^{95}$ It is by no means certain how one should evaluate this balance sheet. At a minimum, the Court plainly is not the unvarnished defender of racial minorities that it sometimes has been cracked up to be.

Thus, even if one believes that courts have made a larger contribution to the story of American freedom than I previously

88. See supra note 17.

89. See, e.g., Harper v. Virginia State Bd. of Elections, 383 U.S. 663 (1966); Terry v. Adams, 345 U.S. 461 (1953); Smith v. Allwright, 321 U.S. 649 (1944); Nixon v. Herndon, 273 U.S. 536 (1927); Guinn v. United States, 238 U.S. 347 (1915).

90. See, e.g., Brown v. Board of Educ., 347 U.S. 483 (1954); Shelley v. Kraemer, 334 U.S. 1 (1948); Buchanan v. Warley, 245 U.S. 60 (1917).

91. See Prigg v. Pennsylvania, 41 U.S. (16 Pet.) 539 (1842).

92. Dred Scott v. Sandford, 60 U.S. (19 How.) 393, 407 (1857).

93. See The Civil Rights Cases, 109 U.S. 3 (1883).

94. See, e.g., Grovey v. Townsend, 295 U.S. 45 (1935); Giles v. Harris, 189 U.S. 475 (1903); Williams v. Mississippi, 170 U.S. 213 (1898); Plessy v. Ferguson, 163 U.S. 537 (1896).

95. See, e.g., Adarand Constructors, Inc. v. Pena, 515 U.S. 200 (1995); Shaw v. Reno, 509 U.S. 630 (1993). 
allowed, it remains uncertain whether they are more likely to advance or to retard the cause of any particular freedom. Is there anything further to be said about which sorts of freedom courts are likely to champion, or is this simply a crapshoot? Given the contestability of what counts as a valid source of constitutional law and the rampant indeterminacy characteristic of the constitutional text, courts probably can marshal adequate "legal" support for advancing just about any freedom cause they are likely to cherish, assuming the requisite backing for that cause in contemporary popular opinion. ${ }^{96}$ But which brands of freedom are likely to resonate best with courts? Because judges are products of contemporary culture, their freedom commitments are likely to reflect in a general way contemporary attitudes toward freedom. For example, both the Supreme Court's validation of racial segregation in 1896 and its invalidation in 1954 generally reflected contemporary attitudes regarding the appropriate scope of freedom for African Americans. ${ }^{97}$

Yet courts are not perfect mirrors of contemporary mores. At a minimum, Supreme Court Justices differ from the average American in three ways: they are more likely to be lawyers, to be well educated, and to be relatively affluent. ${ }^{98}$ These systematic differences undoubtedly influence the sorts of freedom that the Supreme Court is likely to deem worthy of constitutional protection. Lawyers tend to value process, and Supreme Court Justices historically have been more protective of the procedural rights of criminal defendants than has public opinion. ${ }^{99}$ Well-educated people, according to contemporary opinion polls, have systematically different attitudes toward abortion, school prayer, and gay rights than the average member of society. ${ }^{100}$ And the Supreme Court has been

96. For numerous examples of the indeterminacy of the constitutional text, see Michael J. Klarman, Fidelity, Indeterminacy, and the Problem of Constitutional Evil, 65 FORDHAM L. REV. 1739 (1997). For the disagreement over the permissible sources of constitutional interpretation, see LOUIS MICHAEL SEIDMAN, OUR UNSETTLED CONSTITUTION: A NEW DEFENSE OF CONSTITUTIONALISM AND JUDICIAL REVIEW ch. 1 (forthcoming 2001).

97. See Klarman, supra note 32; Klarman, supra note 55.

98. I have further developed this point about the culturally elite biases inherent in judicial review in Michael J. Klarman, What's So Great About Constitutionalism?, 93 Nw. U. L. REV. 145, 189-91 (1998).

99. Miranda probably is the best exemplar of this phenomenon, though dozens of other cases corroborate the point.

100. See Klarman, supra note 98 , at 190 n.245. 
more willing to protect abortion rights, bar school prayer, and invalidate antigay legislation than the average American apparently would like. ${ }^{101}$ Finally, affluent people are more likely to oppose wealth redistribution than the median voter. Historically, the Supreme Court frequently has checked legislative efforts to redistribute wealth, ${ }^{102}$ and on only the rarest of occasions has it attempted to coerce redistribution, and even then in only the mildest of forms. ${ }^{103}$

Thus, while courts have not played a tremendously significant role in the history of American freedom, their interventions predictably have favored those freedoms that affluent, welleducated lawyers tend to value, rather than those touted by less affluent, less well-educated lay people. In a nutshell, we should hardly be surprised that the Supreme Court has offered solid support for the freedom to read books and to express political opinions, ${ }^{104}$ but has done essentially nothing to advance the freedom to keep and bear arms. ${ }^{105}$

Finally, not only have court decisions played a relatively small role in the story of American freedom, and retarded as often as they have advanced the cause of particular freedoms, but they also have sometimes produced extremely unpredictable consequences. Observers probably have been too quick to assume that when courts intervene on the side of a particular freedom, its cause is reliably advanced. Yet Supreme Court decisions often produce the most bizarre consequences. Consider a few of the most salient historical

101. See, e.g., Romer v. Evans, 517 U.S. 620 (1996); Roe v. Wade, 410 U.S. 113 (1973); Engel v. Vitale, 370 U.S. 421 (1962). The gay rights example is complicated by the fact that Supreme Court Justices are also significantly older than the average American, a demographic fact that cuts against tolerant attitudes toward homosexuality. On this culture war issue, then, the bias toward liberal attitudes produced by the Justices' greater education and relative affluence is at least partially offset by the bias toward conservative attitudes produced by their greater age.

102. See, e.g., Lucas v. South Carolina Coastal Council, 505 U.S. 1003 (1992); Buckley v. Valeo, 424 U.S. 1 (1976); Lochner v. New York, 198 U.S. 45 (1905); Pollock v. Farmers Loan \& Trust Co., 158 U.S. 601 (1895); Sturges v. Crowninshield, 17 U.S. (4 Wheat.) 122 (1819). See generally ROBERT G. MCCLOSKEY, THE AMERICAN SUPREME COURT chs. 3-6 (2d ed. 1994).

103. See, e.g., Boddie v. Connecticut, 401 U.S. 371 (1971); Harper v. Virginia State Bd., 383 U.S. 663 (1966); Gideon v. Wainwright, 372 U.S. 335 (1963); Griffin v. Illinois, 351 U.S. 12 (1956).

104. See, e.g., Board of Educ. v. Pico, 457 U.S. 853 (1982); Brandenburg v. Ohio, 395 U.S. 444 (1969).

105. Revealingly, there is no canonical citation to use here. 
examples. Prigg $v$. Pennsylvania ${ }^{106}$ which invalidated a personal liberty law as inconsistent with the Fugitive Slave Act, apparently inspired northern states to enact even more aggressive statutes to protect their free black citizens from kidnapping, thus evading or in some instances outright defying the Court's mandate. ${ }^{107}$ Dred Scott $v$. Sandford mainly served to mobilize Republicans in defense of the legitimacy of their party, which the Court essentially had ruled unconstitutional by invalidating congressional prohibitions on slavery in the federal territories. ${ }^{108}$ Miranda $v$. Arizona not only expanded the freedom of criminal suspects, but also helped elect Richard Nixon president in 1968 , thus leading to the appointment of federal judges less sympathetic to that freedom. ${ }^{109}$ The most dramatic short term impact of Brown $v$. Board of Education was to crystallize southern white resistance to changes in the racial status quo and thus to propel southern politics sharply to the right. ${ }^{110}$ Roe $v$. Wade not only announced a constitutional right to abortion but also mobilized a right-to-life opposition that continues to play a prominent role in American politics to the present day. ${ }^{111}$ Within the last decade, the most palpable consequence of the Hawaii Supreme Court decision invalidating a ban on gay marriage ${ }^{112}$ has been to mobilize thirty state legislatures and Congress to enact statutes reaffirming the traditional heterosexual limitation on marriage. ${ }^{113}$

Thus, even if court decisions matter more to the story of American freedom than I have acknowledged, evaluating their overall consequences is a formidable task. Landmark Court decisions often seem to mobilize political opposition as effectively as

106. 41 U.S. (16 Pet.) 539 (1842).

107. See, e.g., ThOMAS D. MORRIS, FrEe MEN ALl: The PERSONAL LIBERTY LAWS OF THE NORTH, 1780-1861 (1974); Paul Finkelman, Prigg v. Pennsylvania and Northern State Courts: Anti-Slavery Use of a Pro-Slavery Decision, 25 Crv. WAR HIST. 5, 21-35 (1979).

108. See, e.g., DON E. FEHRENBACHER, The DREd ScotT CASE: ITS Significance IN AMERICAN LAW AND POLITICS 561-67 (1978).

109. See Fred P. Graham, The Self-INFlicted Wound chs. 8, 12-13 (1970).

110. See Klarman, supra note 32, at 75-150.

111. See, e.g., JEFFRIES, supra note 76, at 354-59; ROSENBERG, supra note 71, at 188, 341 42.

112. See Baehr v. Lewin, 852 P.2d 44 (Haw. 1993).

113. See, e.g., Hanna Rosin \& Pamela Ferdinand, Gays Achieve Breakthrough in Vermont, WASH. POST, Mar. 17, 2000, at A1. 
they advance the cause of freedom that the Court has identified for constitutional protection.

$* * * * *$

The story of American freedom is complex, multifaceted, and filled with ironic twists and turns. The concept of freedom has proven sufficiently malleable to accommodate both (or all) sides of virtually every significant historical controversy. The tension between positive and negative conceptions of freedom, and between a conception grounded in individual zones of autonomy and a competing notion rooted in the right of political majorities to democratic self-governance, virtually ensures that all contestants will carry their own freedom banner into battle. This is not to say that all claims to freedom will be equally convincing. It is to say that any particular claim must be adjudicated on the merits of the posited freedom, rather than on whether the claim satisfies the criteria for a valid freedom argument.

Particular freedoms expand over time for a variety of reasons. Freedoms that become popularly associated with attractive substantive causes, like the Civil Rights Movement, tend to prosper. Freedoms relating to equality and democracy seem to expand during wartime, as a result of ideologically-articulated war aims, the disruption of traditional patterns of behavior and status that war produces, and the egalitarian implications of equal sacrifice for the common good. Particular freedoms also seem to advance when their opponents are provoked into extreme forms of resistance.

Finally, the role of courts in the story of American freedom is complex and perhaps counterintuitive. Judges are too much a product of their cultural milieu to make more than a marginal contribution to American freedom. Because of the infinite malleability of the concept of freedom, moreover, court decisions that advance one brand of freedom are certain to retard another. Courts are likeliest to promote the freedom causes that resonate with the culturally elite biases of well-educated, relatively affluent lawyers. Yet, because court decisions often mobilize intense political opposition, their overall effect may be to hinder as much as to promote the freedoms identified for judicial protection. 
The only obvious lesson to draw from the story of American freedom is that the subject is a great deal more complicated than it initially appears. 